\title{
Effectiveness of Natura 2000 network in Romanian Alpine Biogeographical Region: an assessment based on forest landscape connectivity
}

\author{
M.I. Niculae, S. Avram, G.O. Vânău, M. Pătroescu
}

Niculae M.I., Avram S., Vânău G.O., Pătroescu M., 2017. Effectiveness of Natura 2000 network in Romanian Alpine Biogeographical Region: an assessment based on forest landscape connectivity. Ann. For. Res. 60(1): 19-32.

Abstract. Maintaining and increasing landscape connectivity, especially of forest landscapes, are some of the main concerns regarding biodiversity conservation. The connectivity of protected areas for different species represents an indicator for evaluating the effectiveness of the Natura 2000 network. Our research aims to evaluate the connectivity of forest landscapes in the Romanian Alpine Biogeographical Region (ABR) for various terrestrial species. We analysed the distribution of forest patches and Sites of Community Importance (SCI), as part of Natura 2000 network, in the Romanian ABR. We evaluated the connectivity of forest patches for terrestrial species with different dispersal distances, identifying those patches with significant contribution to maintain the forest landscape connectivity, through the graph theory approach. To quantify the importance of each node, we evaluated the dPCconnector fraction derived from the $\mathrm{dPC}$ index. Of the 125 SCIs in the Romanian ABR, 71 protected areas have over 1000 ha, four of them have more than 100,000 ha. The total protected surfaces cover $\sim 35 \%$ of the Romanian ABR, and the forest surfaces, protected in SCIs, cover $26 \%$ of the total Romanian ABR. Regarding the connectivity scores, we found that the forest surfaces across the ABR are well connected $(0.89$ or 1 for different dispersal distances) in comparison with the Natura 2000 forest patches. The forest patches are well connected especially for the species with large dispersal distance in both cases $(\mathrm{d}=25 \mathrm{~km})$. For the species characterized by a small dispersion distance, the connectivity is lower $(0.46)$ in the case of protected forests. Our results evidence that the connectivity objective of the forest surfaces protected through the Nature 2000 network is not totally achieved. Furthermore new protected areas are needed where the forest are still present for increasing landscape connectivity for species. Keywords Forest patches, Natura 2000, connectivity, CONEFOR, Alpine Biogeographical Region, Romania

Authors. Mihaiță Iulian Niculae, Gabriel Ovidiu Vânău, Maria Pătroescu - University of Bucharest, Centre for Environmental Research and Impact Studies, 1st Nicolae Balcescu Blvd., Sector 1, CP 010041, Bucharest, Romania; Sorin Avram (avram.sorin32@gmail.com) - University of Craiova, Department of Geography, A. I. Cuza 13, CP 200585, Craiova, Romania \& National Institute for 
Economic Research "Costin C. Kirițescu” of Romanian Academy, Romanian

Academy House, Calea 13 Septembrie, no. 13, Sector 5, Bucharest, Romania.

Manuscript received February 23, 2017; revised April 28, 2017; accepted May 02, 2017; online first May 05, 2017.

\section{Introduction}

Maintaining and enhancing landscape connectivity are some of the main concerns regarding biodiversity conservation strategies and conservation planning (Pascual-Hortal \& Saura 2008, Saura et al. 2011, Niculae et al. 2016, Santini et al. 2016), a different concept than the habitat connectivity, which focuses on the species (Lindemayer \& Fischer 2006). According to an evaluation done in 2015 , conservation status for habitats and species in the European Union needs improvements and efforts from member states to reach targets set in the Forest Strategy and Conservation of Biodiversity Strategy (European Union 2015).

Measures related to maintaining and enhancing the landscape connectivity are mentioned in the Strategic Plan for Biodiversity 20112020, including the Aichi Biodiversity Targets (Secretariat of the Convention on Biological Diversity 2014). Aichi Target 11 aims the expansion of the current protected areas network and the implementation of adequate management measures by 2020 for at least $17 \%$ of the terrestrial and inland aquatic ones, also by providing better connectivity between the different protected areas (Leadley et al. 2014; Secretariat of the Convention on Biological Diversity 2014, Santini et al. 2016).

At the same time, Aichi Target 5 promotes measures to halve habitat loss by 2020, including forest habitats, and to significantly reduce habitat's degradation and fragmentation (Leadley et al. 2014, Secretariat of the Convention on Biological Diversity 2014).

Protecting important biodiversity habitats, including forests, must be done by immediate and effective means, in order to reach these targets. Globally, loss and fragmentation of forest habitats are the main causes of problems for forest species, especially the ones with specific demands for quality and size of habitat (Rochelle et al. 1999, McAlpine et al. 2006).

The sustainable forests management measures may reduce the forest fragmentation and habitat loss due to human forestry activities, principally causing land-use and land-cover change (Rubio et al. 2012), road density or natural factors. These are the some of the main causes determining a lower connectivity of forest landscapes for different terrestrial species. The loss and fragmentation of forest landscapes considerably impact the distribution and the movement of forest species (mammals, reptiles, amphibians), increasing the risk of local extinction for certain species in some forest areas or even SCIs (McAlpine et al. 2006).

Creating protected area, while not sufficient in itself, is one of the most used tools in the conservation planning effort (Margules \& Pressey 2000, Cantu-Salazar \& Gaston 2012, Knorn et al. 2012).

The connectivity of protected areas for different species is a very important indicator for evaluating the effectiveness of the protected area network, including Natura 2000 network. The Natura 2000 network is a pan-European protected areas network and represent the core of the European Union nature and biodiversity policy (Fontaine et al. 2007, EUSTAFOR 2013). This network aimed at improving the conservation status of species and habitats of European interest and to stop biodiversity loss (European Commission, 2008, Pullin et al. 2009). The network includes two categories of protected areas, Special Protection Areas (SPA's) and Sites of Community Importance (SCI's), created in the framework of the two extremely important legal instruments for protection of nature in the European Union, the Habitats Directive and Birds Directive (Ev- 
ans 2012; Popescu et al. 2014). The Sites of Community Importance are created under the auspices of the EU Directive on the conservation of natural habitats and of wild fauna and flora (Habitats Directive) (Pullin et al. 2009, Evans 2012). According to this Directive, the Sites of Community Importance, as part of the Natura 2000 network, created within all Biogeographical regions at European level, help maintain habitats and species of community interest in a good conservation status (Council of European Communities 1992). There are 11 Biogeographical regions in the European Union, delimited in accordance with the Directive Habitats (92/43/EEC) and Emerald network of Areas of Special Conservation Interest (EEA 2016). The Alpine Biogeographical Region (ABR) is extremely important because of the high number of natural and semi-natural ecosystems and habitats it includes (about 90\%) and also for sustaining many endemic species. In this biogeographical region, forest covers around $40 \%$, while $25 \%$ of the total area is grassland (EEA 2002). Five of the 11 European Biogeographical Regions are found in Romania (EEA 2016), but the ABR includes most of large protected areas.

More than half of the Natura 2000 sites, include forest patches, extremely important in order to maintain and improve the conservation status of some species (Merce 2012, Niculae et al. 2016). It is especially worrying that the Natura 2000 isn't still fulfilling its purpose of ensuring reduction of loss and fragmentation of habitats of community interest. According to EEA, protected areas are areas with low fragmentation level, but we consider this level to be underestimated. Increased road network density and deforestation are some of the most important negative influences (EEA 2011, Patru-Stupariu et al. 2015).

Romania started creating its Natura 2000 system of protected areas in 2007, aiming at improving and increasing the connectivity of essential for biodiversity landscapes (Knorn et al. 2012). The species and habitats of community interest, stated in the Habitats Directive and Birds Directive, became the focus for the conservation efforts of Romania (Hartel et al. 2010). Other important changes manifested in Romania in the same period that influenced the conservation issue (Ioja et al. 2010). Some fundamental changes for the protected areas of Romania started once there was a change of political regime in 1989 (Soran et al. 2000, Ioja et al. 2010, Knorn et al. 2012). About 20\% of the country's territory is under some form of protection, as Natura 2000 Sites, natural or national parks, biosphere reserves etc. Also, around $10 \%$ of the national forests are protected (Ioja et al. 2010), most of the protected areas being found in the Carpathian Mountains. The Carpathians are highly important for the conservation of nature, due to the high biodiversity and presence of some important species of large mammals (Knorn et al. 2012). The large carnivores are among the most interesting (bears, wolves, lynxes) (EEA 2011, Rozylowicz et al. 2011).

In Romania, a large part of the forests turned from public to private ownership after the change of political regime in 1989. The management of the forest patches included in protected areas became extremely difficult (Strimbu et al. 2005, Ioja et al. 2010, Knorn et al. 2012). New owners often lack the means and were not interested in conservation, leading to deforestation (Sikor et al. 2009, Ioja et al. 2010; Knorn et al. 2012, Vanonckelen \& van Rompaey 2015), and damage of the overall connectivity.

To evaluate and assist in the conservation of the landscape connectivity, there were developed specific tools that evaluate both the structural and the functional connectivity for some species (Tischendorf \& Fahrig 2000). The most used method in landscape ecology is the graph theory that allows the representation and assessment of landscape connectivity (Ricotta et al. 2000, Urban \& Keitt 2001, Pascual-Hortal \& Saura 2006). The graph theory method enables landscape representation as an interconnected network of patches (Ricotta et al. 2000), the basic components of the net- 
work being the number of habitat patches $(\mathrm{N})$ or nodes and links (L) or connecting elements (Saura \& Hortal 2007, Saura \& Rubio 2010).

Our research proposes an evaluation of the effectiveness of Natura 2000 network in Romanian Alpine Biogeographical Region, analysing the connectivity of the protected forest surfaces, on the one hand, and for the whole forest surfaces (protected and unprotected), on the other hand.

The aims of the study are: (i) to evaluate the distribution of forest patches and Sites of Community Importance (SCI), as part of Natura 2000 network in the Romanian ABR; (ii) to analyse the structural and functional connectivity of forest sites for terrestrial species, and (iii) to identify the forest patches with significant contribution to maintain the forest landscape connectivity.

\section{Materials and methods}

\section{Study area}

The study area was limited to the Alpine Biogeographical Region (ABR). This region covers $50067 \mathrm{~km}^{2}$, which is approximately $21 \%$ of the country's total surface. In Romania, ABR is overlapping the Carpathian Mountains and are divided in three regions: Eastern Carpathians, Southern Carpathians and Western Carpathians (Rey et al. 2007).

Most of the study area is covered by forest ( $\sim 70 \%)$, agricultural fields $(\sim 16.5 \%)$, scrubs and natural pastures $(\sim 11 \%)$ (Figure 1$)$. Forests in the Carpathian Mountains of Romania are broad lives forests, with Fagus sp., Quercus $s p$. and other hhardwood and softwood forests, and coniferous forests, with Abies sp., Picea sp. Pinus sp. and other conifers.

A large part of the forests inside the Roma-

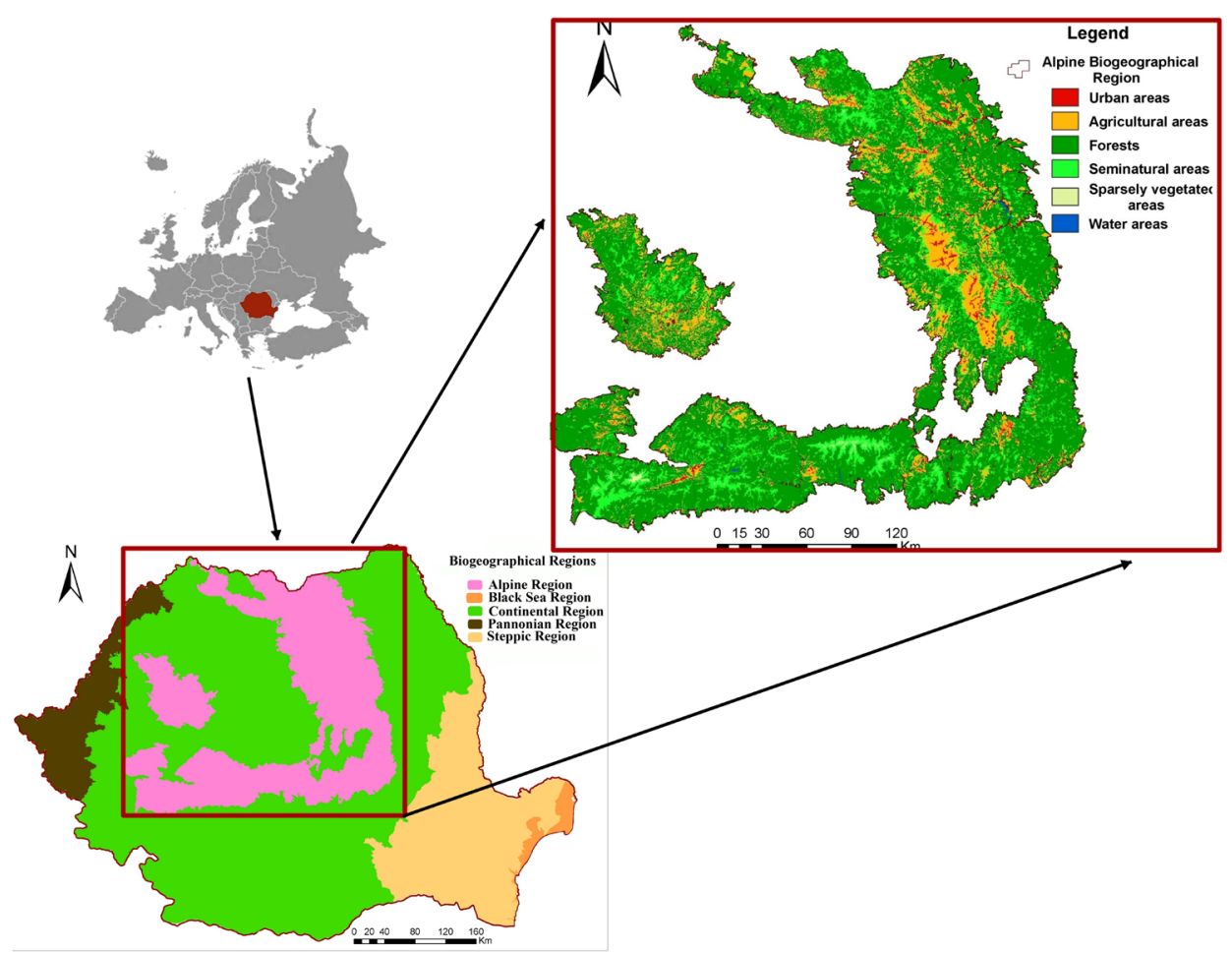

Figure 1 Map of the study area, with ABR main land cover 
nian ABR are pristine forests, Romania being one of the few European countries where these types of forests are still present (beech forests, Oak forests, mixed beech - fir - spruce forests and coniferous forests) (Biriș \& Veen 2005).

\section{Assessment of connectivity}

To evaluate the effectiveness of the Natura 2000 network in Romanian ABR based on analysis of forest landscape connectivity, we used two approaches in this study: firstly, we analysed the protected forest patches included in the Natura 2000 network in the Romanian ABR (only SCI's) (A), and secondly, we analysed all forest surfaces across the Romanian ABR (B).

Our study focused on the connectivity model of the forest surfaces (protected and unprotected) for a generic functional group of terrestrial forest mammals. The connectivity analysis was conducted using different median dispersal distances (d), specific for small to medium mammals or to large mammals. In the case of the forest species, especially mammals, dispersion distance can be estimated as a multiple of the home range size linear dimension. For this study, the connectivity was estimated considering the following dispersion distances: $\mathrm{d}=$ $1 \mathrm{~km}, \mathrm{~d}=5 \mathrm{~km}, \mathrm{~d}=10 \mathrm{~km}$ and $\mathrm{d}=25 \mathrm{~km}$ (Gurrutxaga et al. 2011), for the two cases (A and $\mathrm{B})$. The maximum dispersion distance is different, in relation to the home range area and species body size. The main parameter of the species dispersion is the distance covered by the species, thus the ability of the species to reach a new habitat (Bowman et al. 2002). The dispersion distance is an important indicator used in conservation models (Henein et al. 1998). Dispersion distance for mammals is highly correlated with the species body size (Sutherland et al. 2000), and in this way an important predictor for the average and maximum dispersion distance.

Data regarding the distribution and size of the Natura 2000 Sites of Community Importance that we have used for the present study were extracted from the Ministry of the Environment, Water and Forest database, available at http://www.mmediu.ro/articol/date-gis/434 (Ministry of Environment, Waters and Forests 2015). Information about forest patches distribution in Romanian ABR were extracted from the CORINE Land Cover dataset, year 2012, version 18.5 .1 , format raster, $100 \times 100 \mathrm{~m}$ resolution, available at http://land.copernicus. eu/pan-european/corine-land-cover/clc-2012/ view. The forest patches represent the forest landscape elements and they are defined as homogeneous spatial units by ecological point of view (Rochelle et al. 1999).

Forest connectivity was determined by dividing the aggregate area of forest patches in the largest component to the total area of Natura 2000 forest sites (SCI), included in ABR (A) and to the total area of forest in the whole ABR (B) (Minor \& Lookingbill 2010). The connectivity score ranged from 0 to 1 . If values are close or equal to 1 , forest patches are well connected or very well connected. If values are close or equal to 0 , it means that the forest patches are less connected or disconnected (Minor \& Lookingbill 2010). These values were also corroborated with indices based on binary connection model, NC (number of components) and NL (number of links). Links represent connections between the nodes and the higher the value, the more connected the forest landscape is (Saura \& Pascual-Hortal 2007, Saura \& Torné 2009).

In case of the forest landscape we analysed, dispersion of the species can take place within a component, not between other components (Minor \& Lookingbill 2010). A component or connected region represents a network of patches (nodes) where there is a path between all the pairs of nodes (Saura \& Pascual-Hortal 2007). When the distance between two or more patches is smaller than the dispersion distance of a certain species, these are connected, forming a cluster or component (Ferrari et al. 2007). The lower the number of components, or if the landscape is composed of only one component, the higher connected the 
landscape is. A higher number of components smaller in size indicates the landscape is less well connected (Ferrari et al. 2007, Saura \& Pascual-Hortal 2007). The number of patches, corroborated with the total habitat surface of the largest component offers information about population processes inside that network, with a small number of large components suggesting a well- mixed populations (Minor \& Lookingbill 2010).

The importance of a certain node (dI) in maintaining landscape connectivity expressed by using the Probability of Connectivity index (PC), is calculated as a percent, using (Saura \& Pascual-Hortal 2007):

$d P C(\%)=100 \times \frac{P C-P \text { Cremove }}{P C}$

where: $P C$ - the total value of the index if all the initial nodes are present, while $P C$ remove is the total value after removing a specific node.

The PC index is a habitat availability metrics and is used to quantifying the functional connectivity. PC index shows the probability that two organism living randomly in the landscape are situated in connected habitats, accessible by using the links in that network (Gurrutxaga et al. 2011).

To quantify the importance of each nodes represented by forest patches to maintain the forest patches connectivity, we calculated the dPCconnector fraction using CONEFOR 2.6 software package. The dPc connector measure interpatch connectivity for a certain landscape element (Saura \& Rubio 2010).

The dPCconnector fraction derive from the PC index (Saura \& Pascual-Hortal 2007), which is based on a probabilistic connection model. The PC metrics can be partitioned into three fractions (Bodin \& Saura 2010, Saura \& Rubio 2010):

$d P C=d P C$ intra $+d P C f l u x+d P C$ connector

The value for dPCconnector was calculated for each node in the study area (ABR), for both
A and B case. The calculation were performed for different dispersion distance, $\mathrm{d}=1 \mathrm{~km}, \mathrm{~d}=$ $5 \mathrm{~km}, \mathrm{~d}=10 \mathrm{~km}$ and $\mathrm{d}=25 \mathrm{~km}$ (Gurrutxaga et al. 2011). dPCconnector fraction evaluates how much a certain forest patch contributes to maintain the connectivity between other forest habitat patches by serving as an connecting element or stepping stone that cannot be replaced by other forest patches (Bodin \& Saura 2010, Saura \& Rubio 2010). It depends on the topological position in the forest landscape network (Saura \& Rubio 2010).

If the values of the dPCconnector is higher than 0 it means that node is part of the best path (maximum probability) used for species dispersal between other nodes and that node is important to maintain the connectivity (Bodin \& Saura 2010, Gurrutxaga et al. 2011). When the dPCconnector values equal with 0 it means that node is unconnected.

We used the graph theory approach to measure the connectivity of forest patches (Urban et al. 2009, Minor \& Lookingbill 2010) and the Conefor 2.6 software with graphical user interface (Saura \& Torné 2009), available at http:// www.conefor.org/coneforsensinode.html. For the spatial analysis we used ArcGIS 10.3 software. The node files (forest patches) and connection files (distances) required to perform the connectivity analyses in Conefor 2.6 are extracted through Conefor inputs extension for ArcGIS, available at http://www.jennessent. com/arcgis/conefor_inputs.htm. The connections are characterized by the Euclidean distance between nodes with the distance calculated from feature edges. The resulting files are generated directly in the format required by Conefor 2.6 software (Saura \& Torné 2009).

\section{Results}

\section{SCI'S and forest patches in Romanian ABR}

In the study area (Romanian ABR) there are 125 de Sites of Community Importance (SCI), 
while there are 383 in total in Romania. Of these 125 SCIs, 94.5\% have forest surfaces. The total protected surface is $\sim 17544 \mathrm{~km}^{2}$, which is $\sim 35 \%$ of the Romanian ABR. A number of 71 sites are over 1000 ha, 4 sites over 100000 ha and 54 sites are smaller than 1000 ha. One is less than 1 ha. According to Annex II of the Habitats Directive, in the study area there are 9 species of mammals, 9 species of reptiles and 9 species of amphibians. The bear (Ursus arctos) is present in 71 habitats, the lynx (Lynx lynx) in 63 sites, and the wolf ( $\mathrm{Ca}$ nis lupus) in 61 protected sites.

Analyzing forest patches inside SCIs of the Romanian ABR there were identified 858 forest patches (nodes) (Figure 2.a), 30\% less than the total number of forest patches for the whole Romanian ABR (1223 forest patches) (Figure 2.b).

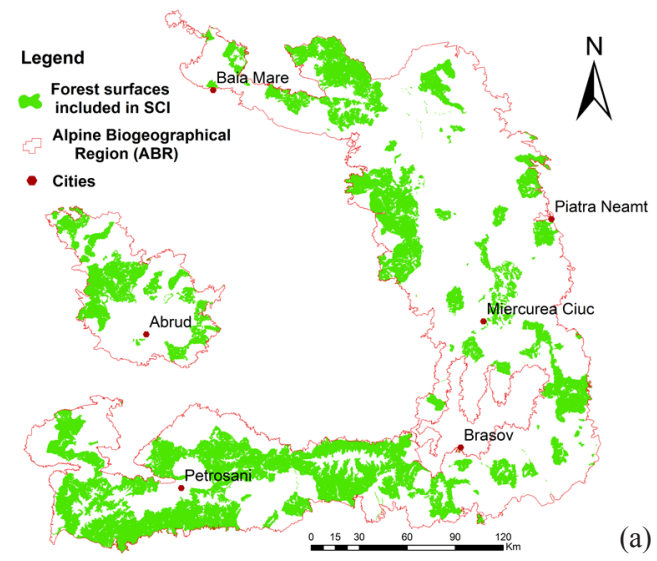

The forest covered surface inside the SCIs of the Romanian ABR is $\sim 13093 \mathrm{~km}^{2}$ (26\% of the total Romanian ABR), $62 \%$ smaller than the forest cover of the whole Romanian ABR $\left(34733 \mathrm{~km}^{2}\right)$ (Table 1).

The average size of the forest patch in SCI is $15.26 \mathrm{~km}^{2}$, smaller by $54 \%$ compared with the average size of the patch at the Romanian ABR level. The analysis shows that $2.6 \%$ of the total forest patches inside SCIs of the Romanian ABR have a surface of over 10000 ha, and $48.5 \%$ less than 10 ha. Three forest patches are larger than 100,000 ha, the largest being 193,488.7 ha, Forest patches over 10000 ha represent $1.55 \%$ of the total Romanian ABR forest patches, while forest patches with a surface less than 10 ha are $13.2 \%$ of the total number of patches. The majority of the patches (59\%) have between 10 and 100 ha. the largest

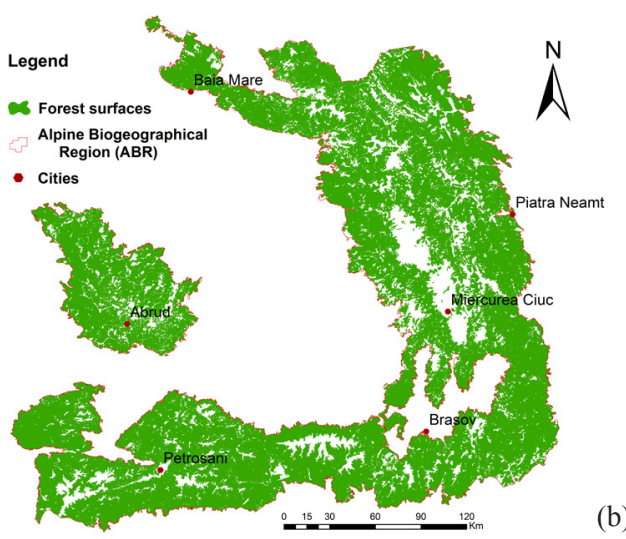

Figure 2 Distribution of the forest patches in SCI overlapping the Romanian ABR (a) and in whole ABR (b)

Table 1 Forest cover and forest patch size inside SCI in comparison with the forest cover of the whole Romanian ABR

\begin{tabular}{llllllll}
\hline $\begin{array}{l}\text { Patch } \\
\text { characteristics }\end{array}$ & $\begin{array}{l}\text { Total } \\
\text { no. of } \\
\text { patches }\end{array}$ & $\begin{array}{l}\text { Total } \\
\text { area } \\
\text { (sq. km) }\end{array}$ & $\begin{array}{l}1-10 \\
\text { ha }\end{array}$ & $\begin{array}{l}10-100 \\
\text { ha }\end{array}$ & $\begin{array}{l}100-1000 \\
\text { ha }\end{array}$ & $\begin{array}{l}1000-10000 \\
\text { ha }\end{array}$ & $\begin{array}{l}>10000 \\
\text { ha }\end{array}$ \\
\hline $\begin{array}{l}\text { A. Natura 2000 } \\
\text { forest patches } \\
\text { from Romanian } \\
\text { ABR }\end{array}$ & 858 & 13093.4 & 416 & 238 & 123 & 59 & 22 \\
\hline $\begin{array}{l}\text { B. Forest patches } \\
\text { across the } \\
\text { Romanian ABR }\end{array}$ & 1223 & 34733.1 & 161 & 716 & 296 & 31 & 19 \\
\hline
\end{tabular}


patch is $779,327.9$ ha. There are also 9 patches over 100,000 ha.

\section{Connectivity analysis of forest sites and their importance as connectivity providers}

The connectivity score varies between 0.46 for species with low dispersion distance $(1 \mathrm{~km})$ and 0.89 for species with long dispersion distance $(25 \mathrm{~km})$. Considering the second case, with the whole forest surface of the Romanian $\mathrm{ABR}$, the connectivity score has a high value of 0.89 for species with reduced or average dispersion distance $(1 \mathrm{~km}, 5 \mathrm{~km}$ and $10 \mathrm{~km})$, reaching the maximum value for species with long dispersion distance, over $25 \mathrm{~km}$ (Table 2).

Total surface of connected forest patches in the largest component varies considering the dispersion distance for each case (A and B). The highest venue is recorded for the network of connected forest patches with a dispersion distance of $25 \mathrm{~km}$, for both forest patches inside SCIS of the Romania ABR (11619.34 $\mathrm{km})^{2}$, and the patches of the whole Romanian ABR (34733.15 km²) (Table 3).

Also, the number of components varies for different dispersion distances considered. Their number decreases from 112 components (d $=1 \mathrm{~km}, 148$ forest patches) to 2 compo- nents $(\mathrm{d}=25 \mathrm{~km}, 688$ forest patches $)$ for forest patches inside SCIs. For the forest patches at Romanian ABR level, included in SCIs or not, the number of components decreases from 18 (d $=1 \mathrm{~km}, 991$ forest patches) to 1 component, network being fully connected $(\mathrm{d}=25 \mathrm{~km}$, 1223 forest patches).

The number of links (NL values) increases by the dispersion distance, allowing movement of individuals between connected forest patches.

Assessing the contribution of each node (forest patch) to maintain the connectivity of the forest landscapes, we found that for the network of forest patches inside SCIs from ABR (A), maximum values of dPCconnector increase with the dispersion distance from $21.002(d=1)$ to $23.978(d=10)$. Afterwards there is a decrease (15.333) for $d=25$ (Figure 3).

When $\mathrm{d}=1$, for 7 nodes the dPCconnector had values higher than 1, 3 higher than 10.577 recorded 0 , being unconnected. Analysis for $\mathrm{d}$ $=5$ and $\mathrm{d}=10$ showed dPCconnector values higher than 1 for 7 nodes. There was a node with values higher than 10 in both cases. There were 549 de nodes with 0 . The largest number of nodes with values higher than 1 were recorded for $\mathrm{d}=2$ (13 nodes), with only 2 over

Table 2 The Connectivity score for different dispersion distances

\begin{tabular}{lcccc}
\hline Connectivity score at ... & $1 \mathrm{~km}$ & $5 \mathrm{~km}$ & $10 \mathrm{~km}$ & $25 \mathrm{~km}$ \\
\hline $\begin{array}{l}\text { A. Natura 2000 forest patches } \\
\text { from ABR }\end{array}$ & 0.46 & 0.48 & 0.50 & 0.89 \\
\hline $\begin{array}{l}\text { B. Forest patches across the } \\
\text { ABR }\end{array}$ & 0.89 & 0.89 & 0.89 & 1 \\
\hline
\end{tabular}

Table $3 \mathrm{NC}$, NL values and surface of the largest component calculated in relation with the dispersion distance (*A. Natura 2000 forest patches from ABR, B. Forest patches across the ABR)

\begin{tabular}{|c|c|c|c|c|c|c|c|c|}
\hline \multirow[b]{2}{*}{$\begin{array}{l}\text { NL, } \\
\text { NC } \\
\text { va- } \\
\text { lues }\end{array}$} & \multicolumn{2}{|c|}{$1 \mathrm{~km}$} & \multicolumn{2}{|c|}{$5 \mathrm{~km}$} & \multicolumn{2}{|c|}{$10 \mathrm{~km}$} & \multicolumn{2}{|c|}{$25 \mathrm{~km}$} \\
\hline & $\begin{array}{l}\text { No. of } \\
\text { compo- } \\
\text { nents } \\
\text { (no. of } \\
\text { links) }\end{array}$ & $\begin{array}{c}\text { Area of } \\
\text { largest } \\
\text { component } \\
\text { (sq. km) }\end{array}$ & $\begin{array}{l}\text { No. of } \\
\text { compo- } \\
\text { nents } \\
\text { (no. of } \\
\text { links) }\end{array}$ & $\begin{array}{c}\text { Area of } \\
\text { largest } \\
\text { component } \\
\text { (sq. km) }\end{array}$ & $\begin{array}{l}\text { No. of } \\
\text { compo- } \\
\text { nents } \\
\text { (no. of } \\
\text { links) }\end{array}$ & $\begin{array}{c}\text { Area of } \\
\text { largest } \\
\text { component } \\
\text { (sq. km) }\end{array}$ & $\begin{array}{l}\text { No. of } \\
\text { compo- } \\
\text { nents } \\
\text { (no. of } \\
\text { links) }\end{array}$ & $\begin{array}{c}\text { Area of } \\
\text { largest } \\
\text { component } \\
\text { (sq. km) }\end{array}$ \\
\hline $\mathrm{A}^{*}$ & $112(1196)$ & 6024.96 & $40(3250)$ & 6283.53 & $18(6578)$ & 6514.18 & $2(18942)$ & 11619.34 \\
\hline B & $18(2170)$ & 30879.6 & $2(6338)$ & 30893.28 & $2(13029)$ & 30893.28 & $1(40983)$ & 34733.15 \\
\hline
\end{tabular}


10, while 507 recorded 0 .

The highest values of the index were recorded for forest patches situated in the SCIs of the Southern Carpathians Mountains. For forest patches inside protected areas, considering low dispersion distances, the highest dPCconnector (over 10) were recorded for SCISs overlapping the Southern Carpathians: ROSCI0085 Frumoasa, ROSCI0087 Grădiștea Muncelului-Ciclovina, ROSCI0188 Parâng, ROSCI0063 Jiului Gorge, ROSCI0129 North of Western Gorj, ROSCI0217 Retezat, ROSCI0236 Strei-Hațeg.

For long dispersion distances, the number of patches with high index values increases. The highest values were recorded for forest patches in the Southern Carpathians: ROSCI0085 Frumoasa, ROSCI0087 Grădiștea Munce-
lului-Ciclovina, ROSCI0188 Parâng, ROSCI0063 Jiului Gorge, ROSCI0122 Făgăraș Mountains, ROSCI0194 Piatra Craiului Mountains and ROSCI0013 Bucegi Mountains. For the network of the total Romanian ABR forest patches (B), the increase of the dispersion distance shows increasing values of the maximum dPCconnector values for each node, from 23.340, when $d=1$, to 25.176 , when $d=$ 25 (Figure 4).

Considering all this information, we see the maximum values of dPCconnector index increases with the dispersion distance, while the number of nodes with values over 10 decreases, from 4 when dispersion distance is 1,5 and 10 , to 2 when $d=25$. Also, the number of unconnected nodes (dPCconnector $=0$ ) varies with the distance and is $853,900,830$ and 894
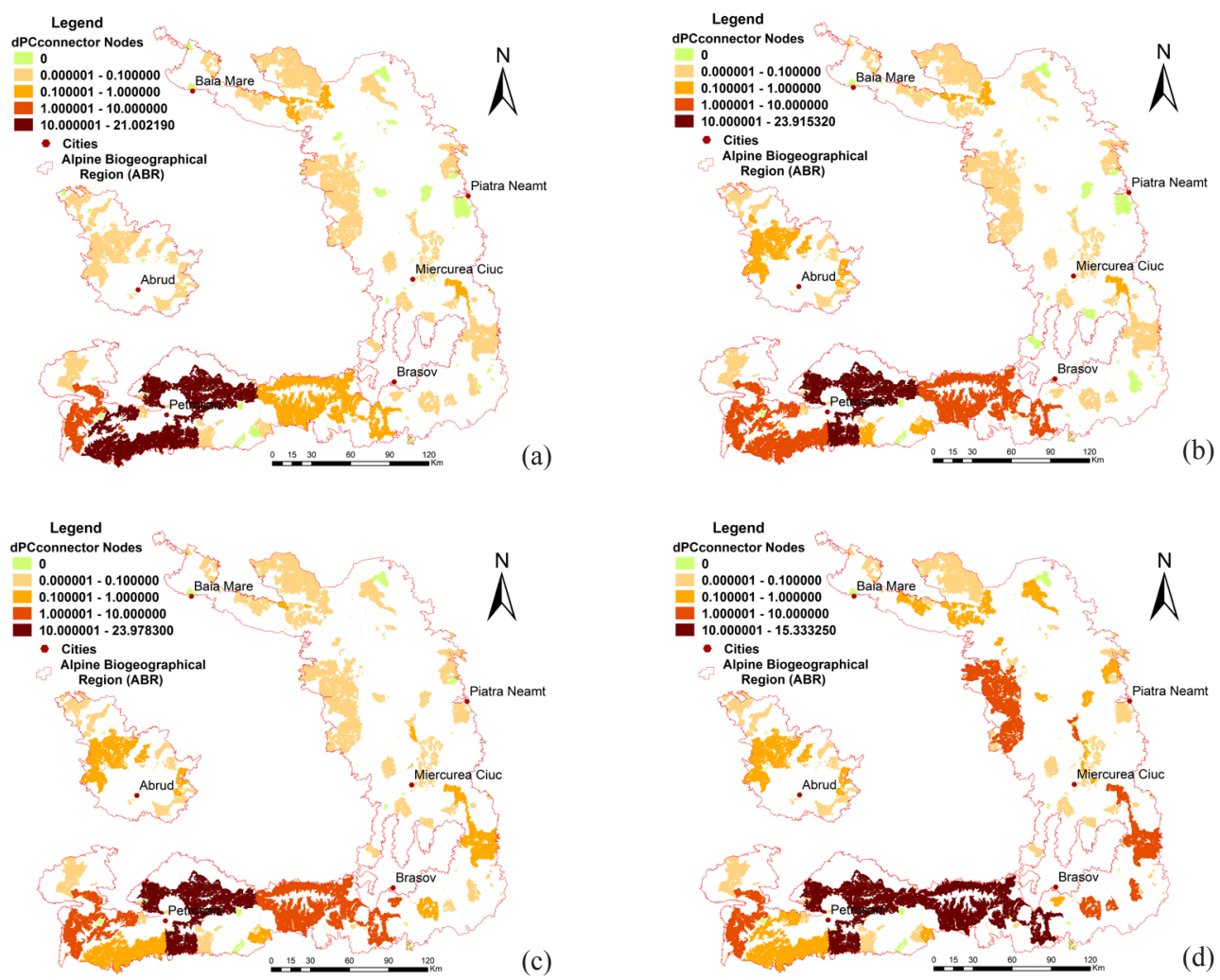

Figure 3 Value of dPCconnector for forest patches included in Natura 2000 network (only SCI) from ABR for different dispersion distances: (a) $d=1 \mathrm{~km}$, (b) $d=5 \mathrm{~km}$, (c) $\mathrm{d}=10 \mathrm{~km}$ and (d) $\mathrm{d}=$ $25 \mathrm{~km}$. 


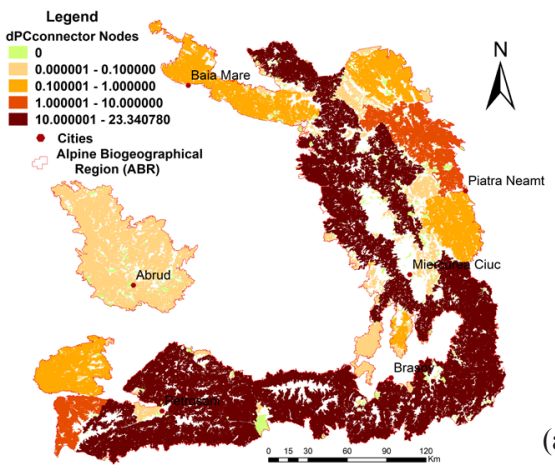

(a)

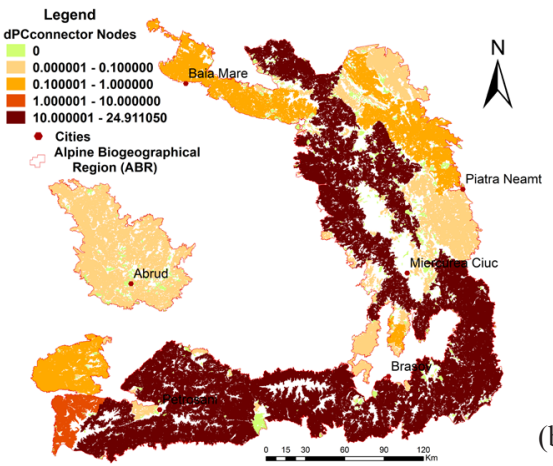

(b)
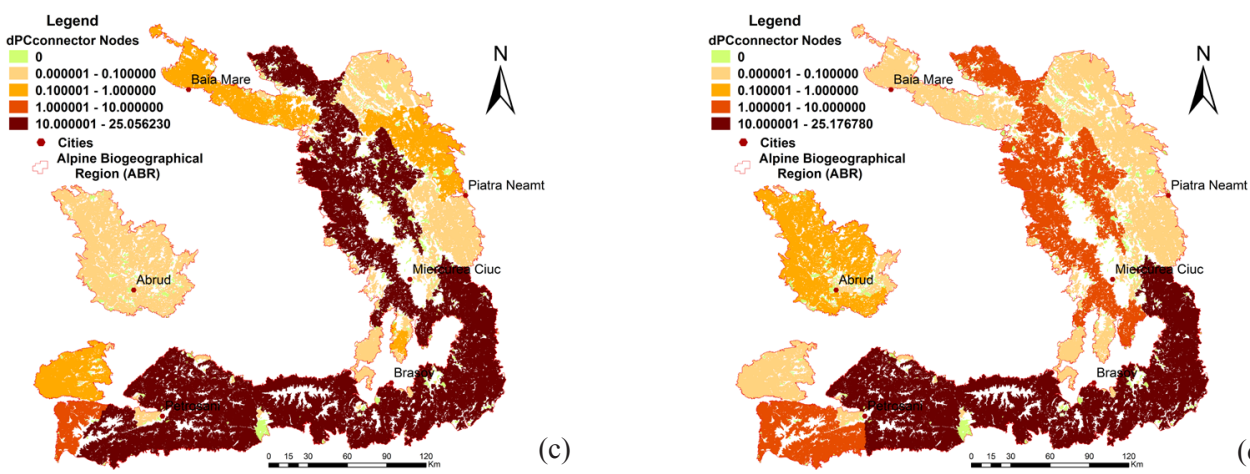

Figure 4 Values of dPCconnector for forest patches across ABR for (a) $d=1 \mathrm{~km},(b) d=5 \mathrm{~km},(c) d=$ $10 \mathrm{~km}$ and $(\mathrm{d}) \mathrm{d}=25 \mathrm{~km}$.

respectively.

The highest values were recorded for forest patches in the Southern Carpathians and Eastern Carpathians.

\section{Discussion}

In Romania, loss of connectivity between habitats is of great concern, important issues being the loss and fragmentation of landscapes.

Our analysis of the forest patches connectivity shows that the connectivity of forest patches for certain species necessity depend on the dispersion distance of those species (Saura \& Rubio 2010). Forest surfaces in Natura 2000 network are less connected for species with short dispersion distance, the connectivity increasing for species with longer dispersion distances. Considering the forest patches in the
Romanian ABR, networks are well connected for groups of species with short dispersion distances and very well connected for species with longer dispersion distance, of $25 \mathrm{~km}$, which is shown by the total surface of the connected forest patches on largest component, with largest value when the dispersion distance is long.

Analysing a number of components (NC) in each network, the connectivity of forest patches increases with the dispersion distance. Diminishing the number of components (two components in case A and one component in case B) for the highest dispersion distance, shows that the two landscapes are well connected and very well connected for those species with large body mass and large home range. Analysis of the contribution of each node (forest patch) in maintaining the forest connectivity shows that this is dependent on 
the dispersion distance and characteristics of the network, especially the number of nodes and territorial distribution (Gurrutxaga et al. 2011). Results prove the irreplaceability value of certain forest patches and can be correlated with other such analysis done for mammal species (Niculae et al. 2016). For mammal species, including large carnivores, it has been shown that the most important forest patches for maintaining the connectivity of the forest landscape are also in the ABR (Niculae et al. 2016). This way, the Romanian ABR is a critical region for the preservation of the forest landscape connectivity in the Natura 2000 network. The SCI sites identified in this region as key connectivity elements have to be considered a priority when applying conservation measures (Niculae et al. 2016). Also, the study shows that a large number of protected forest patches included in SCIs have dPCconnector index values of 0 . These sites being unconnected or isolated (Saura \& Rubio 2010). These are found in SCIs situated mainly in the Eastern Carpathians and in the Carpathians Curvature. After 1990, the most important changes in the forest cover were recorded for the Eastern Carpathians Mountains, determined by deforestation (Rozylowicz et al. 2011, Knorn et al. 2012). In these region, the deforestation activities were the most important both before and after the protected area status was attributed (Maramures, Rodna and Calimani Mountains), with drastic consequences in Maramures region (Knorn et al. 2012). The Southern Carpathians were the least affected by deforestation in the period after 1990, the impact being somewhat more important in the Piatra Craiului and Iezer mountains (Rozylowicz et al. 2011).

The Natura 2000 system of protected areas in the Southern and Western Carpathians must ensure favorable conservation status for the carnivore and other species that find refuge in the forest (Rozylowicz et al. 2011). Large carnivors can be used as umbrella species with positive influence in maintaining the habitat connectivity for other species (Linnell et al.
2005). For smaller species, special management programs must be implemented (Rozylowicz et al. 2011), as these species can't always benefit from the management actions targeted at larger species (Munteanu et al. 2002). Areas situated in proximity to deforested sites, displaying high biodiversity, must be considered a priority for conservation action (Rozylowicz et al. 2011). Also, actions to reduce exploitation of forest patches must be implemented at national and regional scale (Hunter \& Schmiegelow 2010).

According to results of our study, in the Romanian ABR, SCIs cover $35 \%$ of the whole $\mathrm{ABR}$, despite a number of 71 sites with over 100000 ha. Also, the number of forest patches inside SCIs, with a surface of less than 10 ha is rather elevated, indicating a high fragmentation status.

It is recommended that forest patches inside existing SCIs must be protected at all cost, if new patches can't be identified and protected. The most efficient measures for the management of protected areas must be implemented in order to reduce deforestation and promote an equilibrated land use (Ioja et al. 2010). It is a difficult thing to achieve, since many SCIs were established overlapping existing protected areas status (nationa or natural park, biodiversity reserve), but still the intensive forest exploitation wasn't stopped and conservation value was lost. (Strambu et al. 2005, Ioja et al. 2010). In many Romanian Carpathian regions, logging is the main economic activity and source of income (Toader \& Dumitru 2005), and protection action is not efficient enough (Veen et al. 2010).

The recent implementation of forest certification programs such as Forest Stewardship Council (FSC) (Iorgu \& Turturica 2008) can contribute to the reduction in los and fragmentation of forest habitats inside the Romanian ABR. The forest with such a certification are a useful tool for sustainable management of the forest and maintenance of the connectivity (Rozylowicz et al. 2011, Lindenmayer \& Franklin 2002) 
Deforestation affected lots of protected areas, despite the protection measures, among the causes being the lack of means for the protected areas administration, lack of information, poverty of the population in these areas. (Vanonckelen \& van Rompaey 2015). Considering all these, the efficiency of the Natura 2000 area for biodiversity conservation is still in need of improvement (Ioja et al. 2010), and some of the objectives are still to be achieved (Vanonckelen \& van Rompaey 2015)

Our results evidence that the connectivity objective of the protected forest surfaces through the Nature 2000 network is not totally achieved in Romanian ABR and new protected areas are needed where the forest are still present, in order to increase the landscape connectivity for certain species. These measures are absolutely necessary, as the loss of forest cover intensified after 2000.

Still, the efficacy of the network must be assessed considering all the Biogeographical regions in Romania, as it is done at the European Union level (Ioja et al. 2010).

\section{Conclusions}

The implementation of the Natura 2000 in Romania is still to achieve all its objectives. The objective to improve the connectivity for protected forest patches is not fully achieved, especially for species with small body mass, small home range and low dispersion. The connectivity of protected forest surfaces is an indicator which allowed us to identify the most important nodes, critical for maintaining the forest landscape connectivity for species with different characteristics. There is a need to identify new forest habitats to be included in protected areas network in order to ensure adequate dispersion and function as stepping stones using the comparative analysis between the forest patches in SCIs and the forest patches in the whole Romanian ABR. We strongly recommend the upgrade of the Romanian legal provisions and better implementation of the law in order to conserve the forest landscape connectivity, by reducing illegal logging and increase of forest patches sustainably managed.

\section{Aknowledgments}

We would like to thank the two anonymous reviewers for their comments, which improved significantly our paper.

\section{References}

Biriș I.A., Veen P., 2005. Inventory and strategy for sustainable management and protection of vigin forests in Romania. Extended English summary. ICAS and KNNV, $61 \mathrm{p}$.

Bodin Ö., Saura S., 2010. Ranking individual habitat patches as connectivity providers: integrating network analysis and patch removal experiments. Ecol. Model. 221: 2393-2405. DOI: 10.1016/j.ecolmodel.2010.06.017

Bowman J., Jaeger J.A.G., Fahrig L., 2002. Dispersal distance of mammals is proportional to home range size. Ecology 83: 2049-2055. DOI: 10.1890/0012-9658(2002)083[2049:DDOMIP]2.0. $\mathrm{CO} ; 2$

Cantu-Salazar L., Gaston K.J., 2010. Very large protected areas and their contribution to terrestrial biological conservation. BioScience 60(10), 808-818. DOI: 10.1525/ bio.2010.60.10.7

Council of European Communities, 1992. Council Directive $92 / 43 / E E C$ on the conservation of natural habitats and of wild fauna and flora. Official Journal of the European Communities. No L. 206

EEA, 2002. Europe's biodiversity- biogeographical regions and seas. The Alpine region- mountain of Europe. Web: http://www.eea.europa.eu/publications/report 20020524 154909. Accessed: 22.09.2016.

EEA. 2011. Landscape fragmentation in Europe. Joint EEA-FOEN report No. 2/2011. Publications Office of the European Union, $92 \mathrm{p}$.

EEA, 2016. Biogeographical regions. Web: http://www. eea.europa.eu/data-and-maps/data/biogeographical-regions-europe-3. Accessed: 20.09.2016.

European Commission, 2008. Natura 2000.Protecting Europe's biodiversity. Information Press. Oxford, United Kingdom.

EUSTAFOR, 2013. NATURA 2000 Management in European State Forests. European State Forest Association, Brussels, $46 \mathrm{p}$.

Evans D., 2012. Building the European Union's Natura 2000 network. Nature Conservation 1: 11-26. DOI: 
10.3897/natureconservation.1.1808

Ferrari J., Lookingbill T., Neel M., 2007. Two measures of landscape-graph connectivity: assessment across gradients in area and configuration. Landscape Ecology 22:1315-1323. DOI: 10.1007/s10980-007-9121-7

Fontaine B., Bouchet P., Van Achterberg K., AlonsoZarazaga M.A., Araujo R., Asche M., Aspöck U., Audiso P., Aukema B., Bailly N., Balsamo M., Bank R.A., Barnard P., Belfiore C., Bogdanowicz W., Bongers T., Boxshall G., Burckhardt D., Camicas J.-L., Chylarecki P., Crucitti P., Deharveng L., Dubois A., Enghoff H., Faubel A., Fochetti R., Gargominy O., Gibson D., Gibson R., López M.S.G., Goujet D., Harvey M.S., Heller K.-G., Van Helsdingen P., Hoch H., De Jong H., De Jong Y., Karsholt O., Los W., Lundqvist L., Magowski W., Manconi R., Martens J., Massard J.A., Massard-Geimer G., Mcinnes S.J., Mendes L.F., Mey E., Michelsen V., Minelli A., Nielsen C., Nafría J.M.N., Van Nieukerken E.J., Noyes J., Pape T., Pohl H., De Prins W., Ramos M., Ricci C., Roselaar C., Rota E., Schmidt-Rhaesa A., Segers H., Strassen R.Z., Szeptycki A., Thibaud J.-M., Thomas A., Timm T., Van Tol J., Vervoort W., Willmann R., 2007. The European Union's 2010 target: putting rare species in focus. Biological Conservation 139: 167- 185 .

Gurrutxaga M., Rubio L., Saura S., 2011. Key connectors in protected forest area networks and the impact of highways: A transnational case study from the Cantabrian Range to the Western Alps (SW Europe). Landscape and Urban Planning 101: 310-320. DOI: 10.1016/j. landurbplan.2011.02.036

Hartel T., Schweiger O., Öllerer K., Cogalniceanu D., Arntzen J.W., 2010. Amphibian distribution in a traditionally managed rural landscape of EasternEurope: probing the effect of landscape composition. Biological Conservation 143: 1118-1124. DOI: 10.1016/j.biocon.2010.02.006

Henein K., Wegner J., Merriam G., 1998. Population effects of landscape model manipulation on two behaviourally different woodland small mammals. Oikos 81: 168-186. DOI: $10.2307 / 3546479$

Hunter M.L., Schmiegelow F.A., 2010. Wildlife, forests and forestry: principles of managing forests for biological diversity (2nd Edition). Prentice Hall, Upper Saddle River, NJ, 288 p.

Ioja C.I., Patroescu M., Rozylowicz L., Popescu V.D., Verghelet M., Zotta M.I., Felciuc M., 2010. The efficacy of Romania's protected areas network in conserving biodiversity. Biological Conservation. 143: 2468-2476. DOI: 10.1016/j.biocon.2010.06.013

Iorgu O., Turtică M., 2008. Certificarea FSC. Instrument și consecință a managementului forestier responsabil [FSC certification. Instrument and consequence of responsible forest management]. WWW Danube-Carphatian Programme, Brașov, 68 p.

Knorn J., Kuemmerle T., Radeloff V.C., Szabo A., Mîndrescu M., Keeton W.S., Abrudan I., Griffiths P., Gancz V., Hostert P., 2012. Forest restitution and protected area effectiveness in post-socialist Romania. Biolog- ical Conservation 146: 204-212. DOI: 10.1016/j.biocon.2011.12.020

Leadley P.W., Krug C.B., Alkemade R., Pereira H.M., Sumaila U.R., Walpole M., Marques A., Newbold T., Teh L.S.L, van Kolck J., Bellard C., Januchowski-Hartley S.R., Mumby P.J. 2014. Progress towards the Aichi Biodiversity Targets: An Assessment of Biodiversity Trends, Policy Scenarios and Key Actions. Technical Series 78. Secretariat of the Convention on Biological Diversity, Montreal, Canada. 502 p.

Linnell J.D.C., Promberger C., Boitani L., Swenson J.E., Breitenmoser U., Andersen A., 2005. The linkage between conservation strategies for large carnivores and biodiversity: the view from the "half-full" forests of Europe. In: Ray J.C., Redford K.H., Steneck R., berger J.,(ed.), Large carnivores and the conservation of biodiversity. Island Press, Washington: pp. 381-399.

Lindenmayer D.B., Franklin J.F., 2002. Conserving forest biodiversity: a comprehensive multiscaled approach. Island Press, Washington, $352 \mathrm{p}$.

Lindenmayer D.B., Fischer J., 2006. Habitat fragmentation and landscape change: an ecological and conservation synthesis. Island Press, Washington, $352 \mathrm{p}$.

Margules C.R., Pressey R.L., 2000. Systematic conservation planning. Nature 405: 243-253. DOI: $10.1038 / 35012251$

McAlpine C.A., Thodes J.R., Callaghan J.G., Bowen M.E., Lunney D., Mitchell D.L., Pullar D.V., Possingham H.P., 2006. The importance of forest area and configuration relative to local habitat factors for conserving forest mammals: A case study of koalas in Queensland, Australia. Biological Conservation 132: 153-165.DOI: 10.1016/j.biocon.2006.03.021

Merce O., 2012. Natura 2000 and the forests in Romaniamanagement principles, problems and threats. Journal of Horticulture, Forestry and Biotechnology 16: 139144.

Ministry of Environment, Waters and Forests 2015. Date GIS. Limitele in format GIS ale siturilor Natura 2000 [GIS data. GIS format limits of Natura 2000 sites]. Web: http://www.mmediu.ro/articol/date-gis/434. Accessed: 20.09.2016.

Minor E.S., Lookingbill T.R., 2010. A multiscale network analysis of protected-area connectivity for mammals in the United States. Conservation Biology 24(6):15491558 DOI: 10.1111/j.1523-1739.2010.01558.x

Munteanu D., Papadopol A., Weber P., 2002. Atlasul pasarilor clocitoare din Romania [Atlas of the breeding birds of Romania]. Societatea Ornitologică Română, Cluj-Napoca, 152 p.

Munteanu C., Kuemmerle T., Boltiziar M., Butsic V., Gimmi U., Halada L., Kaim D., Király G., KonkolyGyuró É., Kozak J., Lieskovský J., Mojses M., Müller D., Ostafin K., Ostapowicz K., Shandra O., Štych P., Walker S., Radeloff V.C., 2014. Forest and agricultural land change in the Carpathian region- A meta- analysis of long- term patterns and drivers of change. Land Use Policy 38: 685- 697. DOI: 10.1016/j.landusepol.2014.01.012 
Niculae M.I., Niță M.R., Vânău G.O., Pătroescu M., 2016. Evaluating the functional connectivity of Natura 2000 forest patch for mammals in Romania. Procedia Environmental Science 32: 28-37. DOI: 10.1016/j. proenv.2016.03.009

Pascual-Hortal L., Saura S., 2006. Comparison and development of new graph-based landscape connectivity indices: towards the priorization of habitat patches and corridors for conservation. Landscape Ecology 21: 959967. DOI: $10.1007 / \mathrm{s} 10980-006-0013-\mathrm{z}$

Pascual-Hortal L., Saura S., 2008. Integrating landscape connectivity in broad-scale forest planning through a new graph-based habitat availability methodology: application to capercaillie (Tetrao urogallus) in Catalonia (NE Spain). European Journal of Forest Research 127: 23-31. DOI: 10.1007/s10342-006-0165-z

Pătru-Stupariu I., Stupariu M.S., Tudor C.A., Grădinaru S.R., Gavrilidis A., Kienas F., Hersperger A.M., 2015. Landscape fragmentation in Romania's Southern Carpathians: Testing a European assessment with local data. Landscape and Urban Planning 143: 1-8. DOI: 10.1016/j.landurbplan.2015.06.002

Popescu V.D., Rozylowicz L., Niculae I.M., Cucu A.L., Hartel T., 2014. Species, Habitats, Society: An Evaluation of Research Supporting EU's Natura 2000 Network. PLoS ONE 9(11):e113648. DOI: 10.1371/journal.pone. 0113648

Pullin A.S., Baldi A., Can O.E., Dieterich M., Kati V., Livoreil B., Lovei G., Mihok B., Nevin O., Selva N., Sousa-Pinto I., 2009. Conservation focus on Europe: major conservation policy issues that need to be informed by conservation science. Conservation Biology 23: 818824. DOI: 10.1111/j.1523-1739.2009.01283.x

Rey V., Groza O., Ianoş I., Pătroescu M., 2007. Atlas de la Roumanie [Romanian Atlas]. Reclus, Montpelier, Paris, $208 \mathrm{p}$.

Ricotta C., Stanisci A., Avena G.C., Blasi C., 2000. Quantifying the network connectivity of landscape mosaics: a graph- theoretical approach. Community Ecology.1(1): 89-94. DOI: 10.1556/ComEc.1.2000.1.12

Rochelle J.A., Lehmann L.A., Wisniewski J.B., 1999. Forest Fragmentation: Wildlife and Management Implications. Brill: Leiden, The Netherlands, 322 p.

Rozylowicz L., Popescu V.D., Pătroescu M., Chisamera G., 2011. The potential of large carnivores as conservation surrogates in the Romanian Carpathians. Biodiversity and Conservation 20: 561- 579. DOI: $10.1007 /$ s10531-010-9967-x

Rubio L., Rodriguez-Freire M., Mateo- Sanchez M.C., Estreguil G., Saura S., 2012. Sustaining forest landscape connectivity under different land cover change scenarios. Forest Systems 21(2): 223-235. DOI: 10.5424/ fs/2012212-02568

Santini L., Saura S., Rondinini C., 2016. Connectivity of the global network ofprotected areas. Diversity and Distribution 22: 199-211. DOI: 10.1111/ddi.12390

Saura S., Pascual-Hortal L., 2007. Conefor Sensinode 2.2 User's Manual: Software for quantifying the importance of habitat patches for maintaining landscape connectivity through graphs and habitat availability indices. University of Lleida: Spain, $57 \mathrm{p}$.

Saura S., Torné J., 2009. Conefor Sensinode 2.2: a software package for quantifying the importance of habitat patches for landscape connectivity. Environmental Moddeling \& Software 24: 135-139. DOI: 10.1016/j. envsoft.2008.05.005

Saura S., Rubio L., 2010. A common currency for the different ways in which patches and links can contribute to habitat availability and connectivity in the landscape. Ecography 33:523-537. DOI: 10.1111/j.16000587.2009.05760.x

Saura S., Estreguil C., Mouton C., Rodriguez- Freire M., 2011. Network analysis to assess landscape connectivity trends: Application to European forests (1990-2000). Ecological Indicators 11: 407-416. DOI: 10.1016/j. ecolind 2010.06 .011

Secretariat of the Convention on Biological Diversity, 2014. Global Biodiversity Outlook 4. A mid- term assessment of progress towards the implementation of the Strategic Plan for Biodiversity 2011-2020. Montréal. Canada, $156 \mathrm{p}$.

Sikor T., Stahl J., Dorondel S., 2009. Negotiating post-socialist property and state: Struggles over forests in Albania and Romania. Development and Change 40:171193. DOI: $10.1111 / \mathrm{j} .1467-7660.2009 .01510 . x$

Soran V., Biro J., Moldovan O., Ardelean A., 2000. Conservation of biodiversity in Romania. Biodiversity and Conservation 9: 1187-1198. DOI: 10.1023/A:1008905020807

Strîmbu B.M., Hickey G.M., Strîmbu V.G., 2005. Forest conditions and management under rapid legislation change in Romania. Forestry Chronicle 81: 350-358. DOI: $10.5558 / \mathrm{tfc} 81350-3$

Sutherland G.D., Harestad A.S., Price K., Lertzman K.P., 2000. Scaling of natal dispersal distances in terrestrial birds and mammals. Conservation Ecology 4(1): 16.

Tischendorf L., Fahrig L., 2000. How should we measure landscape connectivity? Landscape Ecology 15: 633641. DOI: 10.1023/A:1008177324187

Toader T., Dumitru I., 2005. Romanian forests. National Parks and Natural Parks, Romsilva, Bucharest.

Urban D., Minor E., Treml E., Schick R., 2009. Graph models of habitat mosaics. Ecology Letters 12: 260273. DOI: 10.1111/j.1461-0248.2008.01271.x

Urban D., Keitt T., 2001. Landscape connectivity: a graph theoretic perspective. Ecology. 82: 1205-1218. DOI: 10.1890/0012-9658(2001)082[1205:LCAGTP]2.0. $\mathrm{CO} ; 2$

Vanonckelen S., van Rompaey A., 2015. Spatiotemporal Analysis of the controlling factors of forest cover change in the Romanian Carpathian Mountains. Mountain Research and Development, 35(4): 338-350. DOI: 10.1659/MRD-JOURNAL-D-15-00014

Veen P., Fanta J., Raev I., Biriș I.A., de Smidt J., Maes B., 2010. Virgin forests in Romania and Bulgaria: results of two national inventory projects and their implications for protection. Biodiversity and Conservation 19:18051819. DOI: $10.1007 / \mathrm{s} 10531-010-9804-2$ 